\title{
PM 701 a Highly Selective Anti Cancerous Agent Against L1210 Leukemic Cells: In Vivo Clinical and Histopathological Study
}

\author{
Sabah S. Moshref, FRCS(I) \\ Tissue Culture Unit, King Fahd Medical Research Center \\ and Department of Plastic and Reconstructive Surgery \\ King Abdulaziz University, Jeddah, Saudi Arabia \\ sabahmoshref@hotmail.com
}

\begin{abstract}
Cancer therapy remains a challenging problem. PM 701 is an ideal anti-cancer agent, which selectively targets cancer cells, thereby sparing normal tissues. In the first stage of this study, PM 701 induced programmed cell death (apoptosis) on cancer cells without any side effects on normal cells at tissue culture level. The aim of this study was to test the effect of PM 701 agent on cancer-induced animal models which were successfully produced at our laboratory. L1210 leukemia cells were inoculated intraperitoneally in adult male MFI mice which were divided into 4 groups. Group One - injected intraperitoneally with leukemia cells without treatment; Group Two - injected with L1210 cells and treated with oral administration of (PM 701) at the end of the $1^{\text {st }}$ week; Group Three - received PM 701 only, and Group Four control mice that drank only distilled water. The animal model was successfully produced when the inoculated tumor cells were grown locally and produced distant metastases. This was confirmed by the growth of peritoneal mass, positive blood smear and histopathological study which revealed systemic infiltration of leukemia cells in the liver, lung, kidney, spleen and testes. The use of PM 701 in cancer induced animals indicated its efficacy which showed marked improvement of the animals' clinical condition, improved animal survival rate, negative blood smear; decrease in the size of pertioneal mass, reduction of metastatic deposits in some organs and eradication in others.
\end{abstract}

Keywords: Leukemia cells, L1210, Animal model, Anti-cancer agent, Apoptosis.

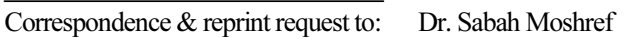




\section{Introduction}

Leukemia has great incidence of local infiltration and distant metastasis. It tends to infiltrate the intra-abdominal structure and induce huge malignant ascites. Successful drug treatment in human disease requires an adequate therapeutic index reflecting the treatment's specific effects on target cells. A drug that induces cell death could prove highly selective for cancer cells. The mechanisms responsible for such death are of obvious importance in determining the efficacy of specific treatments $^{[1]}$. Chemotherapeutic agents known to induce apoptosis are the most successful therapeutic approach, but unfortunately, normal highly dividing cells are also a target for that agent, especially in bone marrow, testes and epithelial tissue ${ }^{[2]}$.

Finding a new, reliable, effective treatment selectively targeting abnormal cells, while saving normal cells, which can cause reduction of tumor size, controlling local and distant metastasis and preventing a relapse of disease with minimal side effects are all the main goals to be achieved by oncologists. Tissue culture and animal model play a crucial role in the development of new therapies. These two modalities were used to study the pathogenesis of disease and to evaluate the effect of therapeutic agents ${ }^{[3]}$.

The aim of this study was to test the anti-cancer effect of PM 701 (natural, cheap, easily available) agent on the cancer-induced animal models which were developed at our animal laboratory unit. PM 701 agent was tested previously at tissue culture level on cultured lung cancer cells (A549), Mice Leukemia Cells L1210, and normal skin fibroblast. PM 701 induced programmed cell death (apoptosis) on cancer cells without any side effect on normal tissues ${ }^{[4]}$.

\section{Materials and Methods}

This study was conducted in King Fahad Medical Research Center (KFMRC), Medical Center at King Abdulaziz University (KAU). MFI mice were used to produce the acquired cancer-induced animal model by intraperitoneal injection of mice leukemia cells - L1210. It was obtained from cell strain at the American Type Culture Collection (ATCC), Rockville, MD USA). Media: The following commercially available media were prepared according to published literature; these include: 
- $\quad$ RPMI - (1640) (10\% FCS). RPMI is a multipurpose medium that was used for cultivation of mammalian cells.

- Phosphate Buffer Saline (PBS) is a phosphate-buffered physiological saline solution. Calcium and Magnesium free solution $^{[5,6]}$.

- Trypsin

Forty male MFI mice with approximately 25-30gm weight were selected from the Animal House in KFMRC, KAU in Jeddah. Animals were housed in standard cages at the animal house and allowed to acclimate to their surroundings for 7 days prior to the experiment. The mice had free access to water and food during the experiment. All animals received standard care according to ethical requirements approved by the Ethic Committee for Animal Research of KAU. The duration of experiment was five months. Lymphocyte leukemia, mice cell L1210 was maintained in RPMI (1640), culture medium (10\% FCS) before inoculated into MFI mice.

Animals were divided into four groups: 10 animals in each group.

- Group One - injected intraperitoneally with a dose of $0.2 \mathrm{ml}$ of leukemia cells $(1 \times 105 / \mathrm{ml}$ of media) without treatment.

- Group Two - injected intraperitoneally with a dose of $0.2 \mathrm{ml}$ of leukemia cells $(1 \times 105 / \mathrm{ml}$ of media $)$ and treated with oral administration of PM 701 (15\% in DW) at the end of $1^{\text {st }}$ week after inoculation.

- Group Three - received PM 701 only (15\% in DW).

- Group Four - control mice drank only distilled water.

Animals were observed for any physical or behavioral changes, and if present, they were reported and photo-documented. Survival rate was also reported for all groups.

- Animals were anesthetized with $4 \mathrm{ml}$ ketamine and Seton (3:1). When the animals were fully anesthetized, they were killed after collecting blood from jugular vein for blood smear. Macroscopical appearance of tumor was reported, then dissected fixed in 10\% neutral buffered formalin for further histopathology study. Specimens were taken from peritoneal mass, liver, lung, kidney, spleen, and testes and were processed for histopathological observation of any tumor metastases. 


\section{Results}

In the present study, the animals of Group One (up to the end of week three following L1210 cell inoculation via intraperitoneal route) showed an increase in weight, loss of appetite and abnormal movement with marked abdominal distension (Fig. 1a).
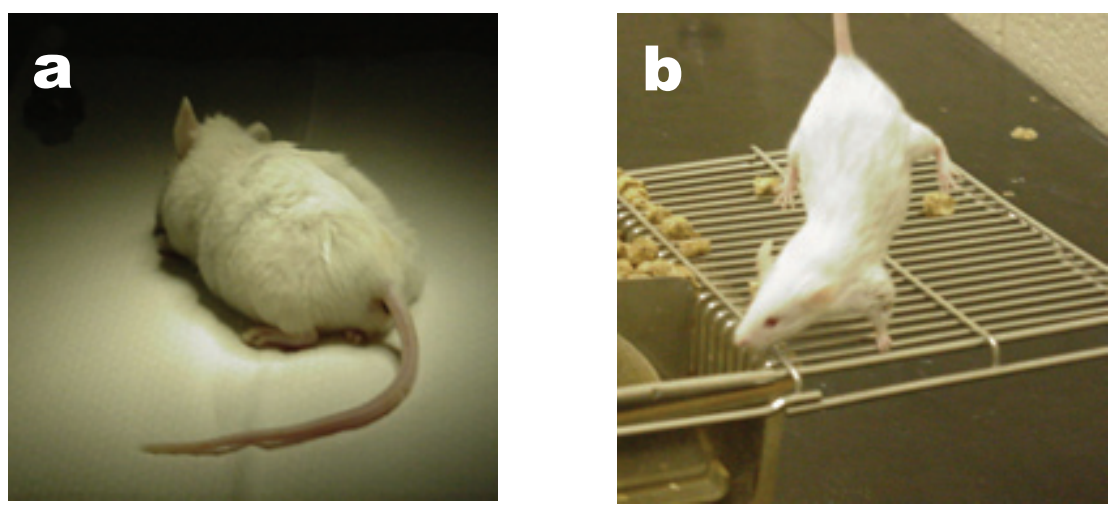

Fig. 1. (a) Morphological feature after inoculation of mice with L1210 with no treatment at end of $3^{\text {rd }}$ week. (b) Morphological feature after inoculation of mice with L1210 and treated with PM 701 at end of $3^{\text {rd }}$ week.

At autopsy, a huge malignant bloody ascite and thin-bodied muscular walls were observed. There was peritoneal mass consisting of friable necrotic tissue. The mass was partially adherent to the posterior abdominal wall with the spread to nearby organs (Fig. 2a,b).
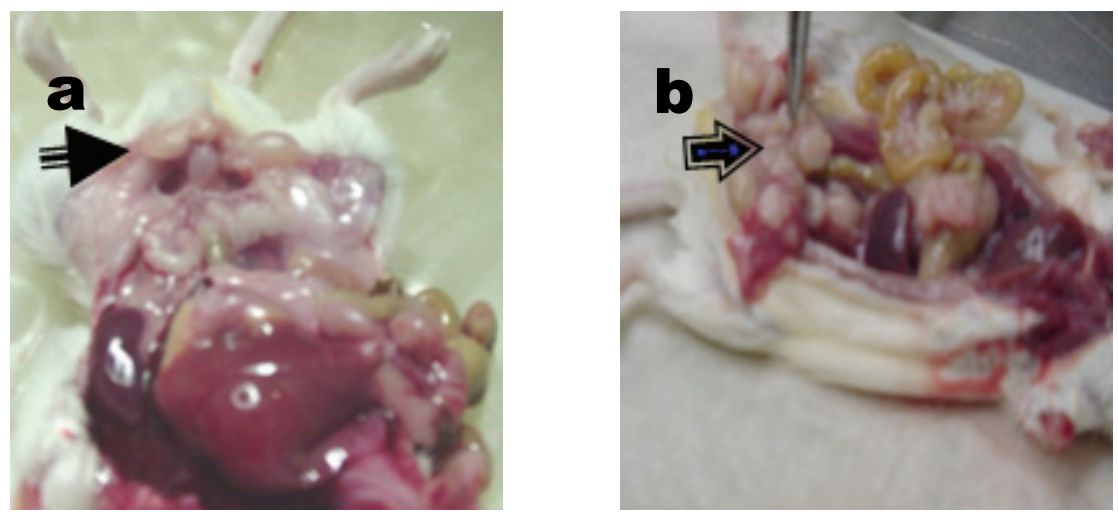

Fig. 2. (a,b) Macroscopical feature of inoculated animal with Leukemia Cells L1210 autopsy with no treatment. A huge malignant ascite was observed; there was peritoneal mass consisting of friable necrotic tissue at 4 weeks. 
Blood smears were positive for L1210 cells (Fig. 3a). Histopathological finding of the abdominal organ revealed no malignant cells. However, toxic changes in the form of hydropic degeneration and focal sinusoidal dilatation were observed in the liver. The lung showed perivascular and peribronchial mixed inflammatory cellular infiltrate. The spleen showed vascular congestion; multinucleated cells of histocytic origin were also observed. By the end of week four, there was infiltration of the liver, lung, and kidney parenchyma with L1210 malignant cells shown in Fig. 4a, 5a, and 6a, respectively.
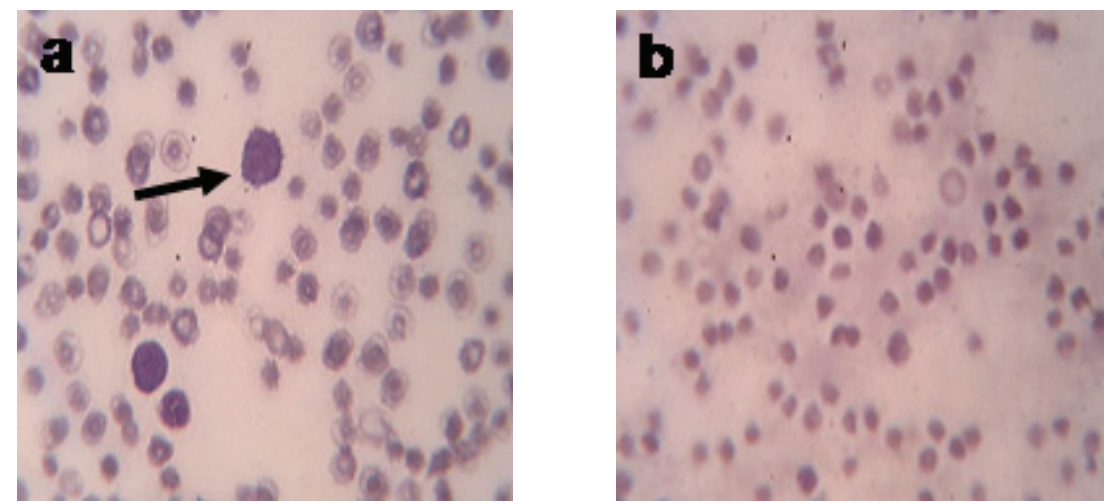

Fig. 3. (a) Study of blood smear of animal model inoculated with L1210 with no treatment. It showed positive blood smear at 4 weeks $\times 40$. (b) Study of blood smear of animal model inoculated with L1210 and treated with PM 701. There was negative blood smear at 4 weeks $\times 40$.
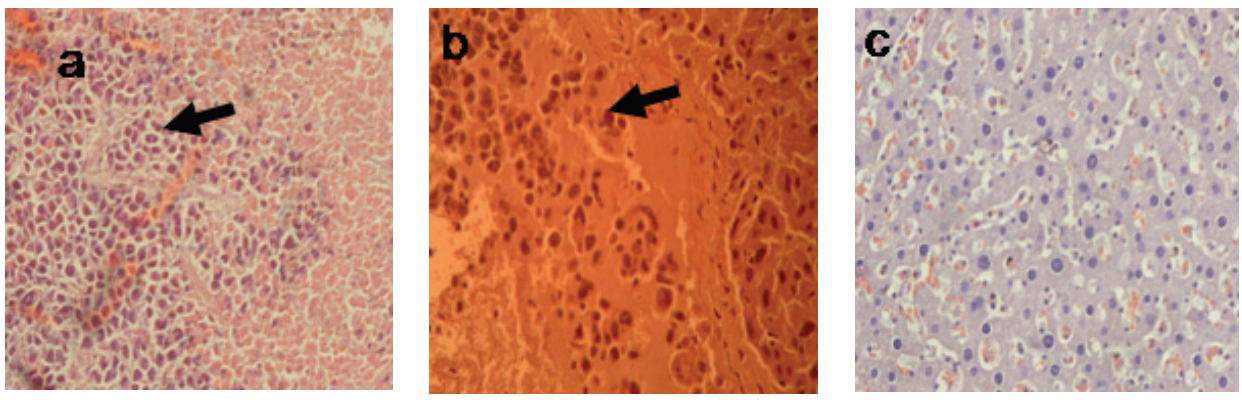

Fig. 4. (a) Histopathology study of the liver of animal model inoculated with L1210 with no treatment. There were devitalized tissue and neoplastic cells at 4 week $\times 40$. (b) Histopathology study of the liver treated with PM 701. There was a residual malignant cell with necrosis at 3 months $\times 40$. (c) Histopathology study of the liver of animal model inoculated with $\mathrm{L} 1210$ and treated with PM 701. There was no malignancy at 5 months $\times 40$. 

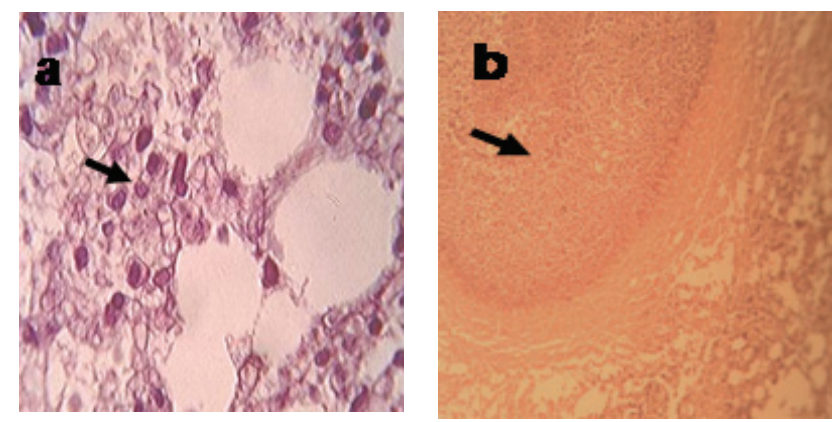

Fig. 5. (a) Histopathology study of the lung of animal model inoculated with L1210 with no treatment. There were highly atypical individual cells at 4 week $\times 40$. (b,c) Histopathology study of the lung of animal model inoculated with L1210, treated with PM 701. There was malignant cell with area of necrosis at 3 months $(b \times 25, c \times 40)$. (d) Histopathology study of the lung of animal model inoculated with L1210 and treated with PM 701. There was no malignancy at 5 months $\times 40$.
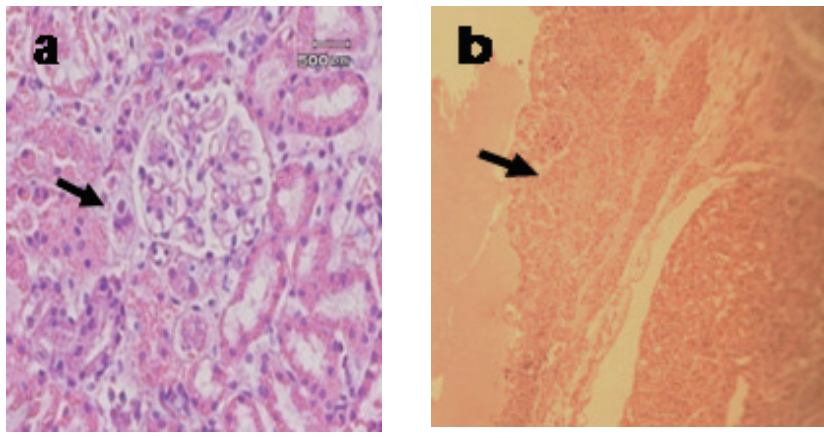

Fig. 6. (a) Histopathology study of the kidney of animal model inoculated with L1210 with no treatment. It showed highly atypical lymphoid cells at 4 week $\times 40$. (b,c) Histopathology study of the kidney of animal model inoculated with L1210, treated with PM 701. There was a tumor cell at the hilum at 3 months $(b \times 25, c \times 40)$. (d) Histopathology study of the kidney of animal model inoculated with L1210 and treated with PM 701. There was no evidence of malignancy at 5 months $\times 25$.
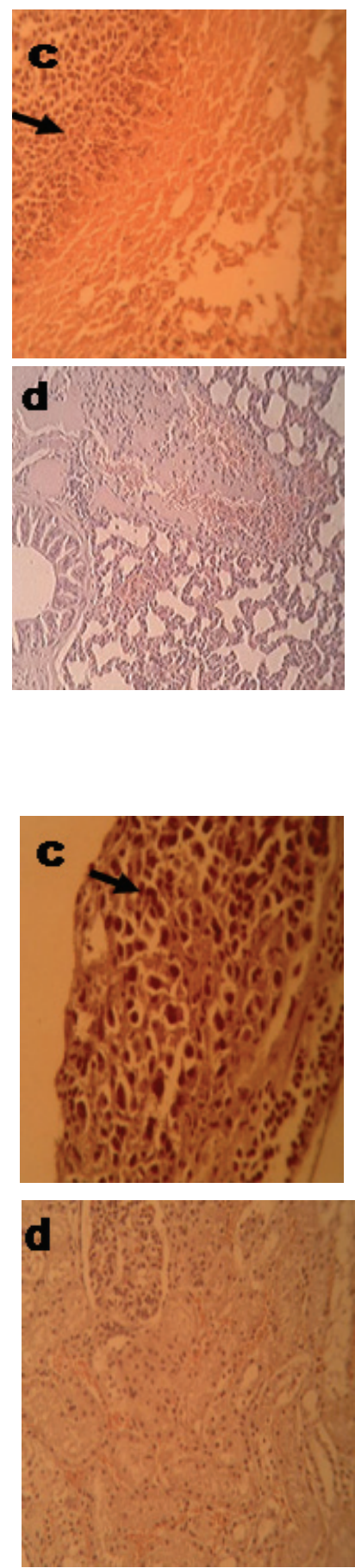

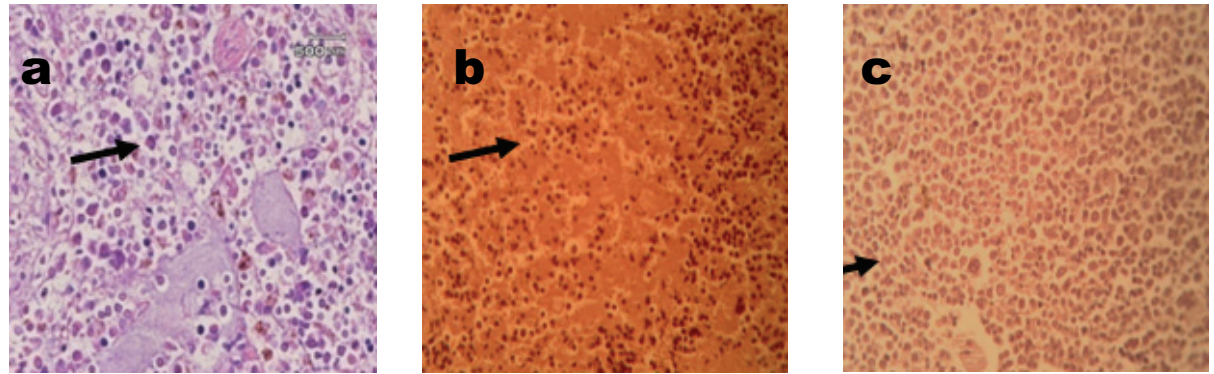

Fig. 7. (a) Histopathology study of the spleen of animal model inoculated with L1210 with no treatment. There were devitalized tissue and neoplastic cells at 4 week $\times 40$. (b) Histopathology study of spleen of animal model inoculated with L1210 and treated with PM 701. There was a focal area of necrosis surrounded by fibrosis at 3 months $\times 40$. (c) Histopathology study of the spleen of animal model inoculated with L1210 and treated with PM 701. There were few degenerated tumor cells at 5 months $\times \mathbf{4 0}$.
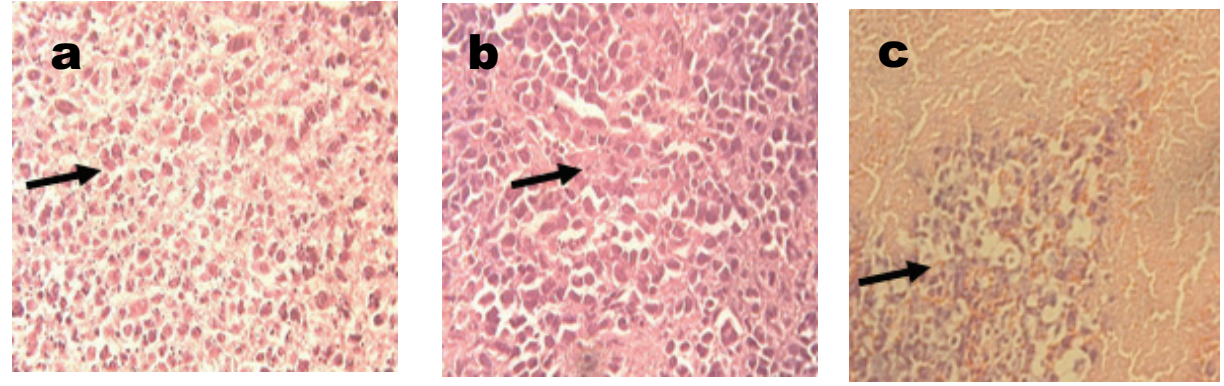

Fig. 8. (a) Histopathology study of peritoneal mass of animal model inoculated with L1210 with no treatment. There was monomorphic cells lymphoma at 4 week $\times 40$. (b) Histopathology study of the peritoneal mass of animal model inoculated with L1210 and treated with PM 701. There was a monomorphic cell lymphoma at 3 months $\times 40$. (c) Histopathology study of the peritoneal mass of animal model inoculated with $\mathrm{L1210}$ and treated with PM 701. There was a residual malignant cell and obvious necrosis at 5 months $\times 40$. 
Histopathological finding of the peritoneal mass and metastatic changes in the examined organs are summarized in (Table 1).

Table 1. Metastatic changes in organs of mice model inoculation with L1210 (no treatment).

\begin{tabular}{|c|c|c|c|}
\hline \multirow{2}{*}{ Organ } & \multicolumn{3}{|c|}{ Period } \\
\hline & Week 1-3 & Week 4-6 & Week 8 \\
\hline Spleen & $\begin{array}{l}\text { Congestion multinucleated cells with no } \\
\text { malignancy }\end{array}$ & Neoplastic cells & \multirow{5}{*}{ 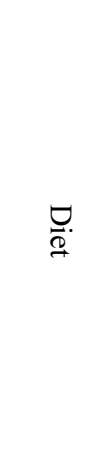 } \\
\hline Liver & $\begin{array}{l}\text { Hydropic degeneration and focal } \\
\text { sinusoidal dilatation } \\
\text { No Malignancy }\end{array}$ & $\begin{array}{l}\text { Degenerated atypical } \\
\text { cells most probably } \\
\text { tumor cells }\end{array}$ & \\
\hline Lung & $\begin{array}{l}\text { Congestion Perivascular, peribronchial } \\
\text { inflammatory cells } \\
\text { No Malignancy }\end{array}$ & $\begin{array}{l}\text { Highly atypical } \\
\text { individual cells }\end{array}$ & \\
\hline Kidney & No Malignancy & Highly atypical cells & \\
\hline $\begin{array}{l}\text { Peritoneal } \\
\text { mass }\end{array}$ & & Malignant cells & \\
\hline
\end{tabular}

The animals of Group Two: At the $4^{\text {th }}$ week following L1210 cell inoculation via intraperitoneal route and treated with PM701; blood smear was negative for L1210 cells (Fig. 3b).

There was general overall marked good health of the animal compared to the previous group, where there was not much change in weight or appetite and normal movement with mild abdominal enlargement Fig. 1b, and there was improvement of survival rate shown.

At autopsy there were mild ascites with congestion of internal organs; there was peritoneal mass but smaller than the mass of the untreated group.

Histopathological examination of abdominal organs revealed unremarkable changes with no malignancy of animal inoculated with L1210 and treated with PM 701.

Histopathological examination of abdominal organs of this group at 3 months, the liver and lung, showed residual necrotic malignant cells (Figs. 4b, 5b, 5c), while the kidney showed tumor cells at the hilum of the kidney (Fig. 6b,c; whereas, b with low power and c with high power). The spleen showed focal areas of necrosis surrounded by fibrosis (Fig. $7 \mathrm{~b}$ ), and the peritoneal mass showed pleomorphic malignant cells (Fig. $8 b)$. 
Further, histopathological examination of abdominal organs of this group at 5 months: the liver (Fig. 4c), lung (Fig. 5d), and kidney (Fig. 6d) showed no malignant deposit, while the spleen showed few degenerated tumor cells (Fig. 7c). The peritoneal mass showed residual malignant cells with marked necrosis (Fig. 8c).

The testicular tissue of animal model inoculated with L1210 after 5 months treated with PM 701 showed a group of degenerated malignant cells with normal spermatogenesis (Fig. 9).
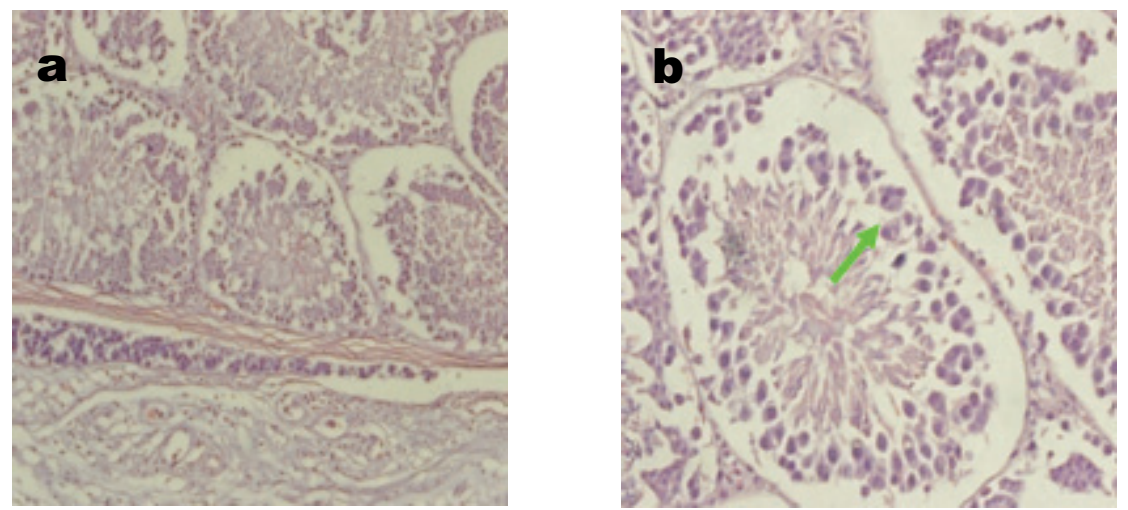

Fig. 9. Histopathology study of the testicular tissue of animal model inoculated with L1210 and treated with PM 701. There was a group of residual degenerated malignant cells with normal spermatogenesis after 5 months $\times 40$.

Table 2. Metastasis changes in organs of mice inoculated with L1210 and treated with PM 701.

\begin{tabular}{|c|l|c|l|l|}
\hline \multirow{2}{*}{ Organ } & \multicolumn{3}{|c|}{ Period } \\
\cline { 2 - 5 } Spleen & $\begin{array}{l}\text { Week 1-3 } \\
\text { Congestion } \\
\text { multinucleated cells } \\
\text { with no malignancy }\end{array}$ & No Malignancy & $\begin{array}{l}\text { Wocal area of } \\
\text { necrosis and } \\
\text { fibrosis }\end{array}$ & $\begin{array}{l}\text { Few } \\
\text { degenerated } \\
\text { tumor cell }\end{array}$ \\
\hline \multirow{2}{*}{ Liver } & $\begin{array}{l}\text { Hydropic } \\
\text { degeneration and } \\
\text { focal sinusoidal } \\
\text { dilatation } \\
\text { No Malignancy }\end{array}$ & No Malignancy & $\begin{array}{l}\text { Residual focus of } \\
\text { malignant cells } \\
\text { with necrosis }\end{array}$ & No Malignancy \\
\hline
\end{tabular}


Table 2. Contd.

\begin{tabular}{|c|c|c|c|c|}
\hline \multirow{2}{*}{ Organ } & \multicolumn{4}{|c|}{ Period } \\
\hline & Week 1-3 & Week 4-6 & 3 Months & 5 Months \\
\hline Lung & \multicolumn{2}{|c|}{ No Malignancy } & $\begin{array}{l}\text { Residual focus of } \\
\text { malignant cells } \\
\text { with focal } \\
\text { necrosis, fibrosis, } \\
\text { and metastasis of } \\
\text { adjacent lymph } \\
\text { node }\end{array}$ & No Malignancy \\
\hline Kidney & \multicolumn{2}{|c|}{ No Malignancy } & $\begin{array}{l}\text { Neoplastic cells } \\
\text { near the hilum }\end{array}$ & No Malignancy \\
\hline $\begin{array}{l}\text { Peritoneal } \\
\text { Mass }\end{array}$ & \multicolumn{2}{|r|}{$\begin{array}{l}\text { Malignant lymphoid } \\
\text { growth }\end{array}$} & $\begin{array}{l}\text { Malignant } \\
\text { lymphoid growth } \\
\text { and degeneration. }\end{array}$ & $\begin{array}{l}\text { Malignant } \\
\text { growth and } \\
\text { degeneration }\end{array}$ \\
\hline
\end{tabular}

The lifespan curve showed that all animals in the non-treated group died after 8 weeks, while $40 \%$ of the treated group remained alive over 5 months (Fig. 10).

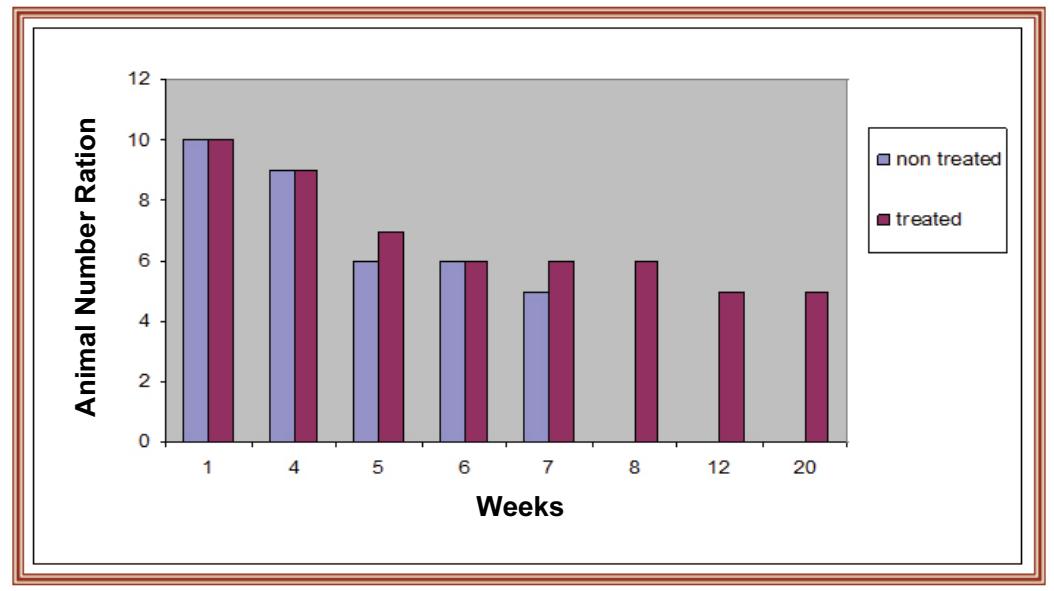

Fig. 10. The lifespan curve showed that the animals in the non treated group died after 8 weeks, while $40 \%$ of the treated group remained alive over 5 months.

\section{Discussion}

The chief goal for using an anti-cancerous agent was to selectively target cancer cells. The mechanisms responsible for such death were of obvious importance in determining the efficacy of specific treatments ${ }^{[1]}$. 
The aim of this study was to test the anti-cancer effect of PM 701 on animal model. Animal model of cancer was successfully developed in the laboratory at KFMRC, KAU, using L1210 leukemic cells inoculated intraperitoneally in MFI mice. Experimental animals were observed to develop malignant ascites by the end of the $3^{\text {rd }}$ week following inoculation.

It was observed from the previous study that PM 701 agent can produce selective cancer cell death at tissue culture level. It had a selective anticancer effect as it killed the cultured lung cancer cells (A459) and L1210 leukemic cells in the tissue culture. The main mechanism of action was by enhancing selective apoptosis of highly dividing cancerous cells sparing normal cells; it also had flourishing effect on normal proliferating skin fibroblasts. The apoptotic effect was detected using hemocytometric analysis of cells treated "in vitro". PM 701 also showed a marked concentration dependent cytotoxicity on L1210 leukemic cells in culture ${ }^{[7]}$. A preliminary study was also carried out and proved a dramatic anticancer effect seen clinically and morphologically in cancer-induced MFI mice with L1210 leukemic cells $^{[8]}$. In the present study PM701 was proven to have an effective anti cancer effect on animal model clinically, morphologically and histopathologically. The criteria of the efficacy of the agent was based on the clinical and morphological changes in mice, the histopathological changes in the local tumor, the metastases in the distant organs and the survival rate of the treated compared to untreated cancer inoculated animals (Tables $1 \& 2$ ).

It was confirmed, by studying the stated criteria, that PM 701 was a promising anticancer agent as it maintained the general good health of the mice clinically and morphologically, and it controlled cancer at early disease by eradication of malignant leukemia cells in the peripheral blood, as indicated by a negative blood smear (Fig. 3b) by the $4^{\text {th }}$ week after treatment of the inoculated and treated group. Therefore, PM 701 can be used as a first line of treatment at early disease to control the disease by reduction of the size of the local tumor and limiting its spread. It can also be used in metastatic disease as it was noticed in the animal with distant metastases at a 3-month period where there was regression of the metastases with some foci of residual tumor cells in some organs such as liver, lung, kidney and spleen as shown in (Fig. 4b, 5b \& c, 6 b \& 
c, 7b, \& 8b). However, when PM 701 agent was given for a longer time, its effect was proven to be more effective as it eradicated the disease after 5 months as was seen in the liver, lung, kidney, and spleen as shown in Fig. 4c, 5d, 6d \& 7c, respectively.

The potential anti-cancerous effect of PM 701 confirms significant improvement in the survival rate of treated animals compared to the untreated group. The lifespan curve (Fig. 10) showed that all animals in the non treated group were dead by 8 weeks $(90 \%$ at 4 weeks, $60 \%$ at 5 weeks, $50 \%$ at 7 weeks; $40 \%$ at 8 weeks; and $0 \%$ after 8 weeks), while the survival rate of the treated group was $(90 \%$ at 4 wks; $70 \%$ at 5 wks; $60 \%$ at $6 \mathrm{wks} ; 50 \%$ at 3 months; and $40 \%$ survived to the end of experiment).

The role of adjuvant chemotherapy was aimed at reducing tumor size, preventing growth progression, stopping distant metastasis and reducing incidence of recurrence ${ }^{[9]}$. Therefore, this agent had significant reduction effect on intraperitoneal mass, with decrease of ascites and improvement of general condition of the animal. PM 701 fulfilled the criteria to be used as adjuvant therapy either preoperatively, to control the size of tumor and to shrink away from vital organs so it became more amenable for excision by surgeon, or post-operatively to prevent recurrence.

By analyzing the response of the animal to PM 701 treatment, it was revealed that it was well tolerated with no side effect as seen in testicular histopathology study, and it did not affect the normally divided cells such as spermatogenesis (Fig. 9a \& b).

\section{Conclusion}

PM 701 agent, which was proved to be an ideal anticancer agent in our previous study at the tissue culture level, was found in this study to be effective anticancer therapy in our animal model, which was inoculated mice with leukemic L1210 cell. The efficacy of PM 701 was indicated either by reduction or eradication of the cancer cells in different metastatic organs, shrinkage of the peritoneal tumor and prolongation of the survival of the inoculated and treated animal group.

Further studies are required to identify the most active fraction of this agent. 


\section{Acknowledgment}

We would like to express thanks to The Scientific Research Council, King Abdulaziz University for their financial support by Grant No. 014/425. In addition, Dr. Solimam Fakeeh and Dr. Solafa A. Aziz Al Bayad, Consultant Pathologist, for her interpretation of the pathological study at Dr. Soliman Fakeeh Hospital; Professor Yasir S. Jamal, professor of Pediatric \& Plastic Surgery, KAUH for revising this article and for helpful suggestions during the course of this study; Dr. Faten Khorshid for her valuable contribution in this project and Mrs. Nagwa T. Heffny for excellent technical assistance.

\section{References}

[1] Sellers WR, Fisher DE. Apoptosis and cancer drug targeting. J Clin Invest 1999; 104(12): 1655-1661.

[2] Johnstone RW, Ruefli AA, Lowe SW. Apoptosis: a link between cancer genetics and chemotherapy. Cell 2002; 108(2): 153-164.

[3] Hillmer MP, MacLeod SM. Experimental keloid scar models: a review of methodological issues. J Cutan Med Surg 2002; 6(4): 354-359.

[4] Khorshid FA, Mushref SS, Heffny NT. An ideal selective anti-cancer agent in vitro: I tissue culture study of human lung cancer cells A549. JKAU Med Sc 2005; 12: 3-19.

[5] Khorshid FA. The effect of the viscosity of the medium in the reaction of cells to topography. Thesis 2003.

[6] Pollared JW, Walker JM. Methods in Molecular Biology. vol. 5: Animal Cell Culture. Clifton, NJ: Human P, 1989. 2-10.

[7] Khorshid FA, Moshref SS. In vitro anticancer agent: I - Tissue culture study of human lung cancer cells A549. II - Tissue Culture Study of Mice Leukemia Cells L1210. Inter J Cancer Res 2006; 2(4): 330-344.

[8] Moshref SS, Khorshid FA, Jamal YS. The effect of PM 701 on mice leukemic cells: Itissue culture study of L1210 (In Vitro) II - In Vivo study on mice. JKAU Med Sc 2006; 13(1): 3-20.

[9] Macaulay VM, Coulter C. Cancer Chemotherapy. In: Clinical Surgery in General. Kirk. RM, Ribbans WJ. $4^{\text {th }}$ ed, London: Churchill Livingstone, 2004. 284-301. 


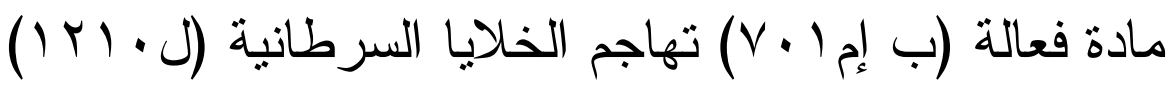
في الفئر ان المتسرطنة: در اسة إكلينيكية ودر اسة نسيجية مرضية

\section{صباح صالح مشرف}

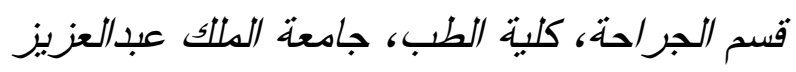

جـدة - المملكة العربية السعودية

المستخلص. يمثل علاج السرطان نقطة تحدي للأطباء المختصين.وبالرغم من القيمة العلاجية للمضادات الكيماوية للسرطان، فإن لها آثار ضارة على الأنسجة السليمة. وقد أثثتت

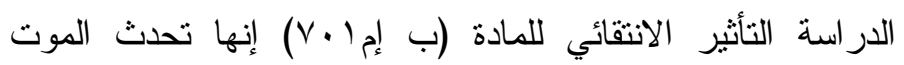

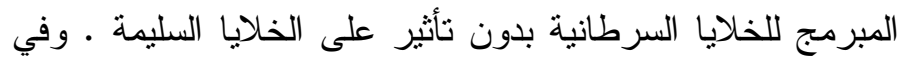
در اساتتا السابقة على كل من خلايا سرطان الرئة (ا 9 ؛0) و الخلايا

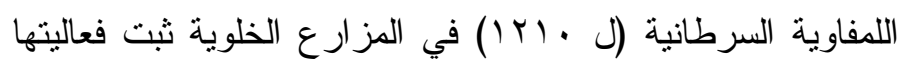

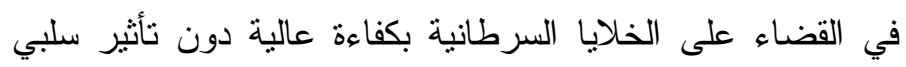

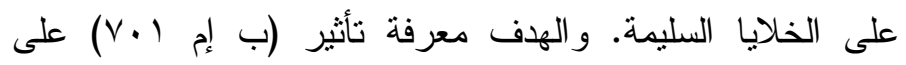

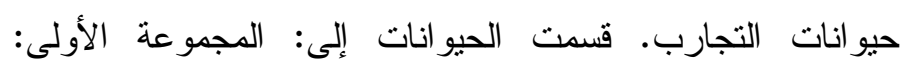

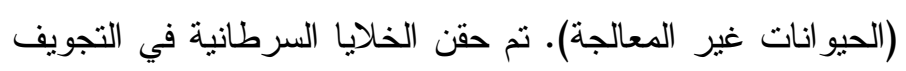

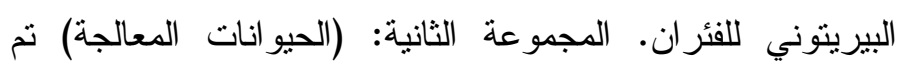

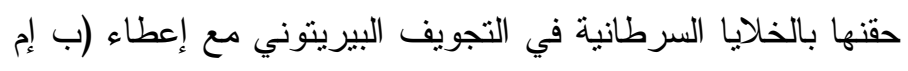

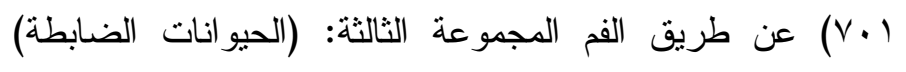

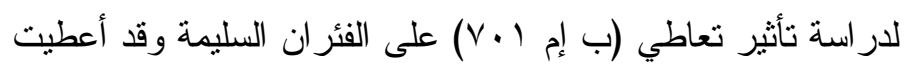

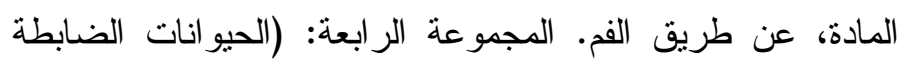

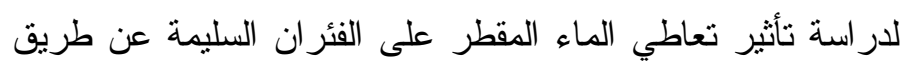


الفم. النتيجة: قد ثبت بالتجربة فعالية المادة (ب إم • V) في علاج الحيو انات المتسرطنة التي تم إنماء الخلايا السرطانية بها، وتمثلت فعالية (ب إم و إطالة عمرها، وخلو الدم من الخلايا السرطانية وضدور الكتلة السرطانية الموضعية بالبريتون؛ و انخفاض نمو الخلايا السرطانية المنتشرة في بعض الأعضاء، واختفاءها بالكامل في الأعضاء الأخرى المصابة. 
